\title{
Genetic and Non Genetic Sources of Variation for Linear body Conformation Traits in Bunaji and Friesian X Bunaji cows
}

\author{
${ }^{1}$ Alphonsus C, ${ }^{1}$ Akpa G . N, ${ }^{1}$ Kpanja E. J, ${ }^{2}$ Finangwai I .H and ${ }^{3}$ Byanet .O \\ ${ }^{1}$ Department of Animal Science, Ahmadu Bello University, Zaria, Nigeria \\ ${ }^{2}$ Department of Agriculture, Federal Collage of Education, Pankshin, \\ ${ }^{3}$ College of Veterinary Medicine, University of Agriculture Makurdi \\ Corresponding author: mcdyems@gmail.com
}

\begin{abstract}
The effects of Age of dam at calving, Sex of calf, Breed, Sire, month of calving and season of lactation on linear body conformation traits was investigated in the dairy herd of the National Animal Production Research Institute, Shika Zaria, Nigeria. Seven linear body conformation traits of 25 Bunaji and 25 crossbred (Friesian $x$ Bunaji) cows were measured. The measurements were taken monthly by 3 evaluators for the complete lactation length of the cows, this resulted in 1275 cumulative records, (with 750 records from Friesian $x$ Bunaji and 525 records from Bunaji). The 7 body conformation traits (stature, chest width, wither height, heart girth, bodylength, body depth and rump width) were measured in centimeter using flexible tape. The results showed that all the genetic and non genetic factors considered had significant effect $(P<0.05)$ on the linear body conformation traits. However, there was no significant $(P>0.05)$ variation amongst the evaluators in their measurements, except $R W$. The body size characteristics increased with age. The male bearing cows were relatively broader $(C W, H G)$ and longer $(B L)$ than the female bearing cows, though there was no significant difference $(P>0.05)$ in their statures (ST) and the body depth (BD). The crossbred cows were taller (ST, HW) longer $(B L)$, broader $(C W, H G)$, but less deep $(B D)$ than the pure Bunaji. The animals of season 1 were taller $(S T, W H)$, deeper $(B D)$ and longer $(B L)$ than the others. However, animals of season 2 and 3 had similar body sizes (ST, $C W, B D, W H, H G, B L$ and $R W$ ). It is therefore suggested that in selecting for body conformation these genetic and non genetic factors should be taken into consideration.
\end{abstract}

Key words: Friesian x Bunaji, linear body conformation, evaluators, breed, sire

\section{INTRODUCTION}

Body conformation is determined by genetic and non genetic factors. The genetic make up of the individual includes additive and non additive genetic combinations that determine growth, these combination interact with both intrinsic factors such as sex, age, physiological status as well as other extrinsic factors such as maternal effect and random 
environmental factors to determine the ultimate phenotypic expression of growth (Arango and Vanvleck, 2002). Linear body measurements taken on live animals have been widely used in research work as a simple means of recording certain aspect of animal growth and shape. Most of linear measurements reflect primarily the length of the long bones of the animal. They indicate when taken sequentially over a period of time, the way in which the animals' body changes in shape, and have been used as a predictor of both animal live weight and carcass composition (Lawrence and fowler, 1998). Linear measurement can be used in assessing growth rate, weight, feed utilization and carcass characteristic in farm animals (Brown,et al., 1972). The importance of body size to efficiency has led to traits associated with size, mass and dimension (such as mature weight, mature height and body measurements) being included in breeding and selection objectives for crossbreeding plans (Arango and Vanvleck,2002). Information on the effects of these genetic and non genetic factors on body conformation traits would help in making appropriate breeding decision.

This study therefore, evaluates the effects of some genetic and non genetic factors on linear body conformation traits of Bunaji and Friesian X Bunaji cows.

\section{Location}

\section{MATERIALS AND METHODS}

The study was conducted on the dairy herd of the National Animal Production Research Institute (NAPRI) Shika, Nigeria, located between latitude $11^{\circ}$ and $12^{\circ} \mathrm{N}$ at an altitude of $640 \mathrm{~m}$ above sea level, and lies within the northern guinea savannah zone (Oni et al., 2001). The mean annual rainfall in this zone is $1,100 \mathrm{~m}$ which commence from May and last till October, of which $90 \%$ falls during the wet rainy season (June September). Following the wet season is a period of dry, cool weather called harmattan, which marks the onset of the dry season, this extends from mid October to January. The dry season (February May) is characterized by very hot weather conditions. At this period daily temperature range from $21^{\circ} \mathrm{C}$ to $36^{\circ} \mathrm{C}$, the mean relative humidity is 21 and $72 \%$ during "harmattan" and the rainy season respectively (Malau Aduli and Abubakar, 1992).

\section{Animals and their Management}

The animals were raised during the rainy season on paddocksown pasture. While hay or silage supplemented with concentrate of undelinted cotton seed cake, were offered during the dry season. They had access to water and salt lick ad-libitum. The animals were maintained on paddock according to sex and physiological status. Unrestricted grazing was allowed under the supervision of the herdsmen for about 79 hour per day. Routine spraying against ticks and other ecto-parasites was observed, while vaccination was carried out against endemic diseases.

\section{Measurements of the Body Conformation Traits}

Seven linear body conformation traits of 25 Bunaji and 25 crossbred (Friesian x Bunaji) cows were measured between year 2007 and 2008. The 7 body conformation traits 
(stature, chest width, wither height, heart girth, body length, body depth and rump width) were measured in centimeter using flexible tape. The measurements were taken by 3 evaluators for the complete lactation length of the cows. Each evaluator was able to take 10 repeated measurements on each of the Friesian $x$ Bunaji, and 8 repeated measurements on each of the Bunaji cows due to there relatively short lactation length,(average 250 days). The data collected by the three evaluators from the 50 cows resulted in 1275 cumulative records (with 525 records from the Bunaji and 750 records from the Friesian $x$ Bunaji). The cows were artificially mated using artificial insemination techniques (A.I) and were checked 30 days later for non return (Conception). Following parturition, the body conformation traits were measured monthly for the complete lactation length of the cows, commencing 34 days post-partum. All measurements were taken immediately before the morning milking while locked in the milking parlour. The Bunaji calves were allowed to run with their dams until weaning at the age of 12 weeks while the cross-bred calves were weaned and bucket fed 34 days post partum, after calves must have taken the colostrums.

\section{Methods of Measurements of Body Conformation Traits}

Stature(ST): Measured from top of the spine in between hips to ground

Height-at-Withers (HW): Highest point over the scapulae vertically to the ground or measured from the highest point on the dorsum of the animal to the ground surface at the level of front legs.

Heart Girth (HG): Measured as a circumference of the body at a point immediately behind the fore legs, perpendicular to the body axis

Chest Width (CW): Measured from the inside surface between the top of the front legs.

Body Depth (BD): Distance between the top of spine and bottom of barrel at last rib, the deepest point independent of stature.

Body Length (DL): Measured from the point of shoulder to the ischium.

Rump Width (RW): The distance between the most posterior points of pin bones

\section{Fixed Factors}

The fixed factors that were considered are: age of dam at calving, evaluators, sex of calf, sire, breed, month of calving, and season of lactation. The seasons were grouped into four (4) according to the weather pattern as follows: Season 1: January March (late dry); Season 2: April June (Early wet); Season 3: July September (Late wet); Season 4: October December (early dry)

\section{Statistical Analysis}

The fixed effects for each body conformation traits were analyzed by least squares techniques using the general linear model procedure of SAS (SAS, 1999). The statistical analysis was based on the general linear model: 
Alphonsus, Akpa, Kpanja, Finangwai \& Byanet

$\mathrm{Y}_{\mathrm{ijklmno}}=\mu+\mathrm{A}_{\mathrm{i}}+\mathrm{B}_{\mathrm{j}}+\mathrm{E}_{\mathrm{k}}+\mathrm{M}_{\mathrm{l}}+\mathrm{S}_{\mathrm{n}}+\mathrm{X}_{\mathrm{o}}+\mathrm{Z}_{\mathrm{p}}+\mathrm{e}_{\mathrm{ijklnop}}$

Where $\mu=$ OveRall Mean

$A_{i}=$ fixed effect of $i^{\text {th }}$ age $(i: 4,5--, 11)$

$B_{j}=$ fixed effect of $j^{\text {th }}$ Breed $(j: B u n a j i$ and Friesian $x$ Bunaji)

$E_{k}=$ fixed effect of $k^{\text {th }}$ evaluators $(k: 1,-3)$

$\mathrm{M}_{1}=$ fixed effect of $\mathrm{l}^{\text {th }}$ month of calving (1: January - June)

$\mathrm{S}_{\mathrm{n}}=$ fixed effect of $\mathrm{n}^{\text {th }}$ Season of lactation $(\mathrm{n}: 1---4)$

$X_{o}=$ fixed effect of $o^{\text {th }}$ Sex of calf $(\mathrm{o}=$ male or female $)$

$\mathrm{Z}_{\mathrm{p}}=$ fixed effect of $\mathrm{p}^{\text {th }}$ sire $(\mathrm{p}=1,2,--6)$

$\mathrm{e}_{\mathrm{ijk} k \mathrm{kn}}=$ random residual error effect.

\section{RESULTS AND DISCUSSION}

The Mean, Coefficient of Variation (CV), Standard Deviation (SD), Minimum and Maximum Values for Body Measurement is shown in Table 1. The body conformation traits measured were less variable, the CVs ranged from $2.74 \%$ (BL) to

Table 1: Summary Statistic of Linear Body Measurements

\begin{tabular}{|c|c|c|c|c|c|}
\hline Traits* $(\mathrm{cm})$ & Mean \pm SE & SD & $\mathbf{C V}$ & Minimum & Maximum \\
\hline Stature & $128.04 \pm 0.17$ & 4.26 & 3.32 & 118.00 & 140.00 \\
\hline Chest width & $23.49 \pm 0.08$ & 2.10 & 8.94 & 18.00 & 27.00 \\
\hline Body depth & $99.30 \pm 0.25$ & 4.29 & 4.32 & 92.00 & 112.00 \\
\hline Height at withers & & 7.16 & 5.73 & 125.00 & 137.00 \\
\hline Heart girth & $173.15 \pm 0.21$ & 8.28 & 4.78 & 154.00 & 199.00 \\
\hline Body length & $121.65 \pm 0.23$ & 3.33 & 2.74 & 114.00 & 128.00 \\
\hline Rump width & $17.52 \pm 0.06$ & 1.04 & 5.94 & 16.00 & 21.00 \\
\hline
\end{tabular}

\section{Effects of Evaluator}

The least square means of the effects of evaluators and number of lactations is shown in Table 2. The effect of the evaluators on the body measurements was not significant $(\mathrm{P}>0.05)$ except RW. This indicates that the evaluators had uniform technique in the measurements of the body conformation traits, except RW, probably due to the difficulty in identifying the pin bones in the fat cows. 
Table 2: Least Squares Means of Effect of Evaluators on Linear Bbody Conformation Traits

\begin{tabular}{lllll}
\hline & \multicolumn{4}{c}{ Evaluators } \\
\hline Measurements (cm) & \multicolumn{1}{c}{$\mathbf{E}_{\mathbf{1}}$} & \multicolumn{1}{c}{$\mathbf{E}_{\mathbf{2}}$} & \multicolumn{1}{c}{$\mathbf{E}_{\mathbf{3}}$} & P-value \\
\hline & Mean \pm SE & Mean \pm SE & Mean \pm SE & \\
\hline Stature & $133.83 \pm 0.16$ & $133.85 \pm 0.16$ & $133.83 \pm 0.15$ & $\mathrm{NS}$ \\
Chest width & $25.19 \pm 0.08$ & $25.20 \pm 0.09$ & $25.20 \pm 0.09$ & $\mathrm{NS}$ \\
Body depth & $103.78 \pm 0.62$ & $103.78 \pm 0.61$ & $103.77 \pm 0.62$ & $\mathrm{NS}$ \\
Height at withers & $130.09 \pm 0.16$ & $130.10 \pm 0.16$ & $130.09 \pm 0.16$ & $\mathrm{NS}$ \\
Heart girth & $177.17 \pm 0.21$ & $178.15 \pm 0.20$ & $177.18 \pm 0.19$ & $\mathrm{NS}$ \\
Body length & $125.87 \pm 0.60$ & $125.88 \pm 0.60$ & $125.85 \pm 0.61$ & $\mathrm{NS}$ \\
Rump width & $18.72 \pm 0.21$ & $19.01 \pm 0.22$ & $18.80 \pm 0.22$ & $*$ \\
\hline
\end{tabular}

E1, E2 and E3 = Evaluator one, two and three, respectively; 1,2,3 = first, second and third lactation; $* \mathrm{P}<0.05$,

\section{Effects of Age}

Generally, the effect of age on body conformation traits, was significant $(\mathrm{P}<0.05)$ as shown in Table 3.Although there was no definite trend of relationship but the older cows (10 to 11 years old) were bigger in size (ST, WH, BD, HG) than the younger. However, the 10 year old cows were relatively taller (ST, WH) with broader $\mathrm{CW}$ and $\mathrm{HG}$, and longer body (BL), but less deeper (BD) than the 11 year old cows. The increase in body size characteristics with age observed in this study is supportive of the previous reports on dairy cows (Kadarmideen, 2004), Yankasa sheep (Akpa et al., 2006) and Goats (Akpa et al., 1998). However, the present results seem to define a limit to such increasing relationship in cows, since the increasing relationship peaked at the $10^{\text {th }}$ year and started declining. This observation needs further investigation. Other authors like Wenzhong et al., (2005); Maiwashe et al,(2002) and Sebhatu et al, (1994) also reported significant influence of age of dam on the body size characteristics. The significant effect of age on the body size characteristics shows that age is a major determinant of growth and physiological development of the animals. It also indicates that the physiological and morphological growth of the animals go concurrently with age. However, such growth usually decreases with advanced age of the animal. 
Alphonsus, Akpa, Kpanja, Finangwai \& Byanet

Table 3: Least Square Means and Standard Error for Effect of Age on Body Conformation

\begin{tabular}{|c|c|c|c|c|c|c|c|c|}
\hline $\begin{array}{l}\text { Age } \\
\text { (Years }\end{array}$ & $\mathbf{N}$ & ST(cm) & $\mathrm{CW}(\mathrm{cm})$ & $\mathrm{BD}(\mathrm{cm})$ & $\mathrm{HW}(\mathrm{cm})$ & HG(cm) & $\mathrm{BL}(\mathrm{cm})$ & $\mathrm{RW}(\mathrm{cm})$ \\
\hline 3 & 172 & $122.83 \pm 0.16^{\mathrm{e}}$ & $21.19 \pm 0.08^{\text {cd }}$ & $97.77 \pm 0.25^{\text {cd }}$ & $121.12 \pm 0.16^{\mathrm{d}}$ & $\pm 166.57 \pm 0.21^{\mathrm{d}}$ & $118.32 \pm 0.23^{\mathrm{d}}$ & $17.41 \pm 0.06^{\text {cd }}$ \\
\hline 5 & 196 & $124.00 \pm 0.20^{\mathrm{de}}$ & $21.69 \pm 0.24^{\mathrm{cd}}$ & $98.00 \pm 0.18^{\mathrm{c}}$ & $120.46 \pm 0.81^{\mathrm{e}}$ & $164.13 \pm 0.20^{\mathrm{d}}$ & $119.00 \pm 0.20^{\mathrm{d}}$ & $17.25 \pm 0.14^{\text {de }}$ \\
\hline 6 & 155 & $125.07 \pm 0.38^{\mathrm{d}}$ & $22.68 \pm 0.21^{\mathrm{b}}$ & $98.36 \pm 0.34^{c}$ & $122.03 \pm 0.38^{\mathrm{cd}}$ & $172.69 \pm 0.93^{\mathrm{bc}}$ & $119.64 \pm-.30^{\text {cd }}$ & $17.11 \pm 0.08^{\text {de }}$ \\
\hline 7 & 147 & $125.75 \pm 0.25^{\mathrm{d}}$ & $22.38 \pm 0.26^{\mathrm{bc}}$ & $97.81 \pm 0.25^{\mathrm{c}}$ & $122.67 \pm 0.28^{\mathrm{cd}}$ & $174.17 \pm 0.15^{\mathrm{bc}}$ & $120.25 \pm 0.48^{\mathrm{bc}}$ & $16.75 \pm 0.17^{\mathrm{e}}$ \\
\hline 8 & 150 & $128.77 \pm 0.39^{c}$ & $22.46 \pm 0.22^{\mathrm{bc}}$ & $99.63 \pm 0.20^{\mathrm{bc}}$ & $126.12 \pm 0.35^{\mathrm{b}}$ & $177.00 \pm 0.54^{\mathrm{b}}$ & $120.08 \pm 0.60^{\mathrm{bc}}$ & $18.61 \pm 0.21^{\mathrm{b}}$ \\
\hline 9 & 165 & $130.03 \pm 0.78^{\mathrm{bc}}$ & $23.13 \pm 0.25^{b}$ & $103.78 \pm 0.61^{\mathrm{b}}$ & $127.45 \pm 0.77^{\mathrm{b}}$ & $177.05 \pm 1.63^{b}$ & $121.87 \pm 0.42^{\mathrm{b}}$ & $17.97 \pm 0.19^{\mathrm{c}}$ \\
\hline 10 & 150 & $135.77 \pm 0.34^{\mathrm{a}}$ & $24.15 \pm 0.60^{\mathrm{a}}$ & $103.23 \pm 0.36^{\mathrm{b}}$ & $133.46 \pm 0.33^{\mathrm{a}}$ & $189.76 \pm 2.30^{\mathrm{a}}$ & $123.50 \pm 0.24^{\mathrm{a}}$ & $19.54 \pm 0.22^{\mathrm{a}}$ \\
\hline 11 & 140 & $132.00 \pm 0.17^{b}$ & $24.12 \pm 0.24^{\mathrm{a}}$ & $106.88 \pm 0.43^{\mathrm{a}}$ & $129.12 \pm 0.17^{\mathrm{a}}$ & $179.00 \pm 0.72^{\mathrm{ab}}$ & $118.76 \pm 0.29^{\text {cd }}$ & $17.53 \pm 0.05^{\mathrm{cd}}$ \\
\hline
\end{tabular}

\section{Effects of Sex, Breed and Sire}

The LSMs for the effect of sex, breed and sire on body conformation is presented in Tables 4. Sex of calf had significant effect $(\mathrm{P}<0.05)$ on the body conformation traits except ST, BD and HW. The male bearing cows were relatively broader $(\mathrm{CW}, \mathrm{HG})$ and longer (BL) than the female bearing cows, though there was no significant difference $(\mathrm{P}>0.05)$ in their height (ST; WH) and the body depth (BD). Sex differences has also been reported in cattle (Alade,1990; Essien and Adesope, 2003) Breed had significant effect $(\mathrm{P}<0.05)$ on body conformation traits. The crosses (Friesian $\mathrm{x}$ Bunaji) were taller (ST, $\mathrm{HW}$ ) longer (BL), broader (CW, HG), but less deeper (BD) than the pure Bunaji. The significant effect of breed on the body conformation traits is an indication that the percentage of Friesian genes in the cross bred cows (Friesian x Bunaji) had significant effects on the conformation traits. There was significant effect $(\mathrm{P}<0.05)$ of sire on the body conformation traits, although no definite trend could be established. However, cows of sire 2 were taller (ST, WH) deeper (BD) and broader (HG), while cows from sire 6 were broader $(\mathrm{CW})$ and longer $(\mathrm{BL})$. The significant effect of sire on the body conformation traits indicates that appropriate breeding plan that will ensure the use of proven sire in the dairy herd combined with good mating system will yield good results. 
Table 4: Least Squares Means and Standard Errors for Body Conformation Traits by Sex, Breed and Sire

\begin{tabular}{|c|c|c|c|c|c|c|c|c|}
\hline $\begin{array}{l}\text { Sex of } \\
\text { Calf }\end{array}$ & $\mathbf{N}$ & $\mathrm{ST}(\mathrm{cm})$ & $\mathrm{CW}(\mathrm{cm})$ & $\mathrm{BD}(\mathrm{cm})$ & $\mathrm{HW}(\mathrm{cm})$ & HG(cm) & $\mathrm{BL}(\mathrm{cm})$ & RW(cm) \\
\hline Male & 679 & $127.92 \pm 0.25$ & $23.82 \pm 0.13^{a}$ & $98.99 \pm 0.25$ & $124.58 \pm 0.57$ & $173.99 \pm 0.43^{\mathrm{a}}$ & $122.05 \pm 0.24^{a}$ & $17.39 \pm 0.06^{b}$ \\
\hline Female & 616 & $128.92 \pm 0.39$ & 23 & $99.70 \pm 0.39$ & $125.71 \pm 0.38$ & $172.05 \pm 0.79^{b}$ & $121.13 \pm 0.23^{b}$ & $17.69 \pm 0.09^{\mathrm{a}}$ \\
\hline \multicolumn{9}{|l|}{ Breed } \\
\hline Bunaji & 525 & $127.40 \pm 0.43^{b}$ & $22.12 \pm 0.25^{\mathrm{b}}$ & $100.66 \pm 0.91^{a}$ & $124.20 \pm 0.09^{b}$ & $172.34 \pm 0.21^{b}$ & $120.13 \pm 0.33^{b}$ & $17.61 \pm 0.32^{\mathrm{a}}$ \\
\hline $\mathrm{F} \times \mathrm{B}$ & 750 & $128.83 \pm 0.08^{\mathrm{a}}$ & $25.19 \pm 0.31^{\mathrm{a}}$ & $97.63 \pm 0.12^{b}$ & $126.12 \pm 0.19^{a}$ & $174.17 \pm 0.12^{\mathrm{a}}$ & $123.52 \pm 0.21^{\mathrm{a}}$ & $17.41 \pm 0.12^{\mathrm{a}}$ \\
\hline \multicolumn{9}{|l|}{ Sire } \\
\hline 1222 & $124.88 \pm 0.41^{\mathrm{e}}$ & $22.51 \pm 0.13^{\mathrm{c}}$ & $98.29 \pm 0.54^{\mathrm{c}}$ & $120.65 \pm 0.20^{\circ}$ & $166.14 \pm 0.46^{d}$ & $119.35 \pm 0.41^{\mathrm{d}}$ & $17.13 \pm 0.16^{d}$ & \\
\hline 2197 & $132.90 \pm 0.38^{\mathrm{a}}$ & $22.55 \pm 0.34^{\mathrm{c}}$ & $102.05 \pm 0.74^{\mathrm{a}}$ & $130.12 \pm 0.69^{\mathrm{a}}$ & $183.98 \pm 0.54^{\mathrm{a}}$ & $121.57 \pm 0.21^{\circ}$ & $18.38 \pm 0.25^{\mathrm{a}}$ & \\
\hline 3186 & $127.57 \pm 0.74^{d}$ & $22.31 \pm 0.22^{\mathrm{c}}$ & $102.77 \pm 0.56^{\mathrm{a}}$ & $125.31 \pm 0.48^{d}$ & $182.92 \pm 0.14^{a}$ & $121.58 \pm 0.58^{\circ}$ & $19.07 \pm 0.39^{\mathrm{a}}$ & \\
\hline 4206 & $127.33 \pm 0.53^{\mathrm{d}}$ & $20.96 \pm 0.18^{\mathrm{d}}$ & $103.71 \pm 0.36^{\mathrm{a}}$ & $125.65 \pm 0.96^{\circ}$ & $168.53 \pm 0.09^{d}$ & $119.61 \pm 0.45^{\mathrm{d}}$ & $17.09 \pm 0.43^{\mathrm{d}}$ & \\
\hline 5219 & $128.07 \pm 0.26^{\mathrm{c}}$ & $24.95 \pm 0.30^{\mathrm{b}}$ & $96.36 \pm 0.44^{d}$ & $126.55 \pm 0.36^{\circ}$ & $173.19 \pm 0.19^{c}$ & $122.34 \pm 0.34^{b}$ & $17.29 \pm 0.34^{c}$ & \\
\hline $6 \quad 245$ & $130.18 \pm 0.34^{\mathrm{b}}$ & $25.63 \pm 0.56^{\text {П }}$ & $99.87 \pm 0.18^{\mathrm{d}}$ & $127.11 \pm 0.22^{\mathrm{b}}$ & $175.90 \pm 0.30^{b}$ & $125.61 \pm 0.51^{\mathrm{a}}$ & $17.79 \pm 0.25^{\mathrm{c}}$ & \\
\hline
\end{tabular}

\section{Effects of Month and Season of Lactation}

The LSM for the effect of month of calving and season of lactation on the body conformation traits is shown in Table 5. Month of calving had significant effect $(\mathrm{P}<0.05)$ on all the body conformation traits measured. The effect of month of calving on the body conformation is usually related to the stages in the wet and dry weather cycle at which an animal reaches a given age; and relative rankings of month of calving groups might be expected to change from stage to stage. (FAO,2008). Also the season of lactation had significant effect $(\mathrm{P}<0.05)$ on the body conformation traits with the animals of season 1 being taller (ST, WH), deeper (BD) with longer body (BL) than the others. However, animals of season 2 and 3 had similar body sizes (ST, CW, BD, WH, HG, BL and RW). The significant effect of season on the conformation traits is in agreement with the earlier observations of Akpa et al; (2006) and Gebeyehu et al. (2007). However, this result is contrary to the observation of Nsoso et al. (2003) that BW and HG were not apparently sensitive to effect of season. The significant effect of month of calving and season of lactation showed that there is a high contribution of the environment to the growth and development of the body conformation traits. Thus, poor management and other environmental stress may affect the efficient growth of the cows. 
Table 5: Least Squares Means and Standard Error for Body Conformation Traits by Month of Calving and Season of Lactation

\begin{tabular}{|c|c|c|c|c|c|c|c|c|}
\hline $\begin{array}{l}\text { Month } \\
\text { Of } \\
\text { calving }\end{array}$ & $\mathbf{N}$ & ST(cm) & $\mathrm{CW}(\mathrm{cm})$ & $\mathrm{BD}(\mathrm{cm})$ & HW(cm) & HG(cm) & BL(cm) & RW(cm) \\
\hline January & 250 & $130.35 \pm 0.58^{\circ}$ & $24.00 \pm 0.58$ & $100.77 \pm 0.52^{20}$ & $128.03 \pm 0.53^{\circ}$ & $181.68 \pm 0.81^{2}$ & $123.85 \pm 0.29^{\prime \prime}$ & $18.10 \pm 0.15^{\circ}$ \\
\hline February & 269 & $125.47 \pm 0.21^{\mathrm{b}}$ & $21.35 \pm 0.43^{b}$ & $99.36 \pm 0.38^{b c}$ & $122.76 \pm 0.24^{\mathrm{ab}}$ & $165.18 \pm 1.60^{d}$ & $122.76 \pm 0.44^{\text {Л }}$ & $16.76 \pm 0.20^{\mathrm{d}}$ \\
\hline April & 272 & $126.86 \pm 0.22^{b}$ & $24.52 \pm 0.09^{\pi}$ & $96.23 \pm 0.19^{d}$ & $124.24 \pm 0.25^{\mathrm{bc}}$ & $170.10 \pm 0.29^{c}$ & $119.22 \pm 0.14^{\mathrm{b}}$ & $17.31 \pm 0.07^{\mathrm{b}}$ \\
\hline May226 & $129.50 \pm 0.33^{\mathrm{a}}$ & $23.91 \pm 0.25^{\pi}$ & $101.47 \pm 0.45^{\pi}$ & $126.57 \pm 0.32^{\text {cd }}$ & $173.89 \pm 0.34^{b}$ & $122.93 \pm 0.39^{\mathrm{a}}$ & $17.60 \pm 0.08^{b}$ & \\
\hline June 258 & $125.29 \pm 0.39^{b}$ & $21.40 \pm 0.13^{b}$ & $98.67 \pm 0.33^{\mathrm{c}}$ & $120.78 \pm 1.56^{d}$ & $166.93 \pm 1.02^{\mathrm{d}}$ & $120.15 \pm 0.29^{b}$ & $17.10 \pm 0.09^{\mathrm{c}}$ & \\
\hline \multicolumn{9}{|l|}{ Season } \\
\hline \multicolumn{9}{|l|}{ of } \\
\hline \multicolumn{9}{|l|}{ Lactation } \\
\hline 1381 & $132.31 \pm 0.81^{\mathrm{a}}$ & $23.61 \pm 0.26^{\mathrm{b}}$ & $102.73 \pm 0.75^{\mathrm{a}}$ & $130.17 \pm 0.72^{\mathrm{a}}$ & $184.93 \pm 1.15^{\mathrm{a}}$ & $122.98 \pm 0.37^{\mathrm{a}}$ & $18.69 \pm 0.19^{a}$ & \\
\hline 2311 & $127.29 \pm 0.32^{\mathrm{b}}$ & $23.45 \pm 0.22^{b}$ & $98.51 \pm 0.37^{\mathrm{bc}}$ & $124.56 \pm 0.30^{b}$ & $171.34 \pm 0.05^{b}$ & $121.32 \pm 032^{b}$ & $17.19 \pm 0.09^{\circ}$ & \\
\hline 3280 & $127.12 \pm 0.24^{b}$ & $23.18 \pm 0.16^{b}$ & $99.09 \pm 0.28^{b}$ & $123.66 \pm 0.74^{b}$ & $170.79 \pm 0.48^{b}$ & $121.36 \pm 0.25^{\mathrm{b}}$ & $17.24 \pm 0.05^{\mathrm{c}}$ & \\
\hline 4303 & $127.67 \pm 0.50^{\mathrm{b}}$ & $24.45 \pm 0.24^{\pi}$ & $97.74 \pm 0.40^{\circ}$ & $124.64 \pm 0.51^{\mathrm{b}}$ & $171.00 \pm 0.91^{\mathrm{b}}$ & $121.75 \pm 0.53^{\mathrm{b}}$ & $17.75 \pm 0.09^{b}$ & \\
\hline
\end{tabular}

\section{CONCLUSION}

Findings of this study revealed that linear body conformation traits of Bunaji and Bunaji crossbred were predominantly influenced by age, sex of calf, breed and sire, month of calving and season of lactation. It is therefore suggested that in selecting for body conformation traits these factors should be taken into consideration.

\section{REFERENCES}

Akpa, G. N., Duru S, and T.T. Amos (1998). Influence of Strain and Sex on Estimation of Within-Age-Group Body Weight of Nigerian Maradi Goats from their Linear Body Measurement. Tropical Agriculture (Trinindad) 4: 462 - 467.

Akpa, G. N., Galadima M. A. and A. E. O. Malau-Aduli (2006). Factors Affecting Milk Production Traits of Friesian Bunaji Crossbred Cows Reared in Northern Nigeria. Production Agriculture and Technology. Nigeria.2(1):78- 84.

Alade, N.K 1990. Genetic Characterization of Linear Measurements of N'dama at Various Ages in the Humid Tropic of Nigeria. M sc Project, Department of Animal Science, University of Ibadan. 
Arango, J. A. and Van Vleck L. D. (2002). Size of Beef Cows: Early Ideas, New Developments. Genet. Mol. Res. 1(1): 51-63.

Essien A and Adesope O.M (2003). Linear Body Measurements of N'dama Calves at 12 Month in South Western Zone of Nigeria. Livestock Research for Rural Development 15:4-9

Gebeyehu G, Belihu K and Berihum A 2007 Effect of Parity, Season and Year on Reproductive Performance and Herd Life of Friesian Cows at Stella Private Dairy Farm, Ethiopia. Livestock Research for Rural Development 19(7): 2007.

Kadarmideen H N 2004 Genetic Correlations Among Body Condition Score, Somatic Cell Score, Milk Production, Fertility and Conformation Traits in Dairy Cows. Animal Science. 2004, 79: 191- 201.

Lawrence T I J and Fowler V R (1998) Growth on Farm Animals. CAB International pp. 271- 283.

Maiwashe, A.N., Bradfield, M.J., Theron, H..E nd J.B Vamwyk,(2002). Genetic Parameter Estimates for Body Measurements and Growth Traits in South African Bonsmara Cattle. Livestock Production Science. 75 (3): 293-300.

Malau Aduli A. E. O. and Abubakar B. Y. 1992 Estimation of 305 Day Yield from Milk Yield in Bunaji and Friesian Bunaji Crosses. Nigeria Journal of Animal production 19(1\&2): 141143

Nsoso S J, Aganga AA, Moganetsi B P and Tshwenyane S O 2003 Body Weight, Body Condition Score and Heart Girth in Indigenous Tswana Goats During the Dry and Wet Seasons in Southeast Botswana. Livestock Research for Rural Development 4(15): 1-6.

Oni O O, Adeyinka I. A, Afolayan R A, Nwagu B I, Malau-Aduli AE O, Alawa C B I and Lamidi O S 2001 Relationships Between Milk Yield, Post Partum Body Weight and Reproductive Performance in Friesian x Bunaji Cattle. AsianAustralian Journal, 14 (11):1516 1519.

SAS 1999. SAS User's Guide Version 8.1. Statistical Analysis System Institute Inc, Cary, Nc, USA. 
Alphonsus, Akpa, Kpanja, Finangwai \& Byanet

Sebhatu, Gebrellul Leon, S. Sartin iii. Mitchell theancho (1994). Genetic and Non Genetic Effect on the Growth and Mortality of Alphine Nubian and Cross Bred Kids. Small Rumin. Res. 13: 166-176

Wenzhong ,Liu., Zhang Yuan and Zhong Xiao,Zhou (2005). Adjustment for Non Genetic Effect on Body Weight and Size in Angora Goats. Small Ruminant Research. 59(1): 25-31 